\title{
PENGARUH EKSTRAK DAUN MIMBA (Azadirachta indica A. JUSS) TERHADAP MORTALITAS HAMA LALAT BUAH CABAI \\ (Bactrocera dorsalis L.)
}

\author{
Juanda $^{1}$ dan Edi M. Jayadi ${ }^{2}$ \\ 1Jurusan Tadris IPA Biologi FITK IAIN Mataram \\ 2 Dosen Jurusan Tadris IPA Biologi FITK IAIN Mataram
}

\begin{abstract}
Abstrak
Lalat buah cabai merupakan hama utama pada tanaman cabai. Lalat buah cabai dapat dikendalikan dengan berbagai jenis insektisida, salah satunya adalah insektisida nabati yang salah satunya dengan memanfaatkan daun mimba. Penelitian ini bertujuan untuk mengetahui pengaruh ekstrak daun mimba untuk mengendalikan hama lalat buah cabai pada stadium larva, pupa dan imago. Jenis penelitian ini adalah eksperimen dengan pendekatan kuantitatif. Populasi pada penelitian ini adalah semua larva, pupa dan imago hama lalat buah cabai yang dibiakkan. Penelitian ini menggunakan lima perlakuan dan lima ulangan dengan sampel penelitian 10 ekor untuk tiap ulangan. Adapun kesimpulan dari penelitian ini adalah ekstrak daun mimba tidak memliki pengaruh yang nyata untuk mengendalikan hama pupa lalat buah cabai sedangkan pada larva dan imago ekstrak daun mimba memliki pengaruh yang nyata untuk mengendalikan hama tersebut.
\end{abstract}

Kata kunci : lalat buah cabai, ekstrak daun mimba, larva, pupa, dan imago. 


\section{PENDAHULUAN}

Praktik budidaya tanaman sayur selalu dijumpai berbagai masalah. Salah satu masalah yang selalu dihadapi adalah kerusakan tanaman oleh hama. Hama yang menyerang tanaman ini kebanyakan golongan serangga. Serangga hama dapat mengakibatkan kuantitas dan kualitas hasil tanaman menurun, bahkan sering kali dapat menggagalkan panen. Untuk mempertahankan kuantitas dan kualitas maka perlu dilakukan tindakan pengendalian hama dengan lebih baik. Sekalipun tanaman cabai rawit relatif tahan terhadap serangan hama dan penyakit ketimbang cabai merah, bukan berarti bebas dari serangan hama dan penyakit yang ada. Bila tidak dirawat dengan baik, maka cabai rawit bisa terserang hama ataupun penyakit tertentu yang mengakibatkan tanaman rusak, pertumbuhannya terhambat, atau bahkan mati.

Serangan lalat buah pada cabai ditandai adanya noda hitam pada pangkal buah. Titik hitam merupakan manifestasi telur lalat buah betina. Di dalam buah, telur akan menetas menjadi ulat. Ulatulat yang telah menetas akan memakan buah cabai. Selanjutnya, di bagian kulit cabai, titik hitam tersebut melebar dan menyebabkan pembusukan buah. Buah yang telah busuk akan rontok. Jika di dalam buah yang busuk tersebut masih terdapat ulat, maka akan menginfeksi tanaman cabai lainnya. Hal ini disebabkan ulat buah memiliki kemampuan melompat dengan cara melentingkan badannya. Jika ulat-ulat tersebut sudah kenyang memakan buah cabai, maka akan membentuk puva (kepompong) di dalam tanah.

Masalah kerusakan tanaman akibat serangga hama merupakan bagian budidaya pertanian sejak manusia mengusahakan pertanian ribuan tahun yang lalu. Manusia dengan sengaja menanam untuk memperoleh suatu keuntungan sehingga dapat digunakan sebagai pemenuhan kebutuhan sandang dan makanan. Namun pada setiap usaha manusia selalu mengalami gangguan-gangguan oleh pesaing yang berupa hewan yang ikut memakan tanaman yang diusahakannya. Karena itu hewanhewan pesaing dan pemakan tanaman tersebut kemudian dianggap sebagai musuh manusia atau hama.

98 BIOTA: Jurnal Tadris IPA Biologi FITK IAIN Mataram 
Pengendalian serangga hama agar tidak menimbulkan kerusakan secara ekonomi pada suatu daerah atau tanaman dapat dilakukan dengan beberapa cara seperti, pengendalian dengan Undang-Undang atau peraturan, secara kultur teknik, secara fisik dan mekanik, secara hayati (Biologi), dan secara kimiawi. Pada kenyataannya pengendalian hama yang dilakukan oleh para petani saat ini adalah kebanyakan menggunakan pestisida kimia tanpa pernah memikirkan dampak dari penggunaan pestisida kimia. Lebih-lebih dengan menggunakan dosis yang tidak sesuai atau berlebihan dapat menimbulkan dampak seperti meninggalkan residu yang bisa merusak lingkunan ataupun yang lainnya.

Salah satu alternatif yang dapat dilakukan untuk mengatasi masalah tersebut adalah penggunaan pestisida nabati. Penggunaan pestisida nabati selain dapat mengurangi pencemaran lingkungan, harganya relatif lebih murah apabila dibandingkan dengan harga pestisida kimia/sintesis. Pestisida nabati dapat dibuat dengan menggunakan tekhnologi tinggi dan dikerjakan dalam skala industri. Namun, dapat pula dibuat dengan menggunakan tekhnologi sederhana oleh kelompok tani atau perorangan. Pestisida nabati yang dibuat secara sederhana dapat berupa larutan, hasil parutan, rendaman ekstrak, dan rebusan bagian daun, biji, dan buah.

Bahan yang digunakan dalam penelitian ini adalah daun tumbuhan mimba, di mana tumbuhan mimba mengandung bahan aktif terbanyak berupa azadirachtin $\left(\mathrm{C}_{35} \mathrm{H}_{44} \mathrm{O}_{16}\right)$ yang merupakan racun bagi hama dan penyakit tanaman atau yang lebih dikenal dengan organisme pengganggu tanaman. Zat ini dapat ditemukan baik pada daun mimba atau biji mimba, akan tetapi kandungan azadirachtin pada daun mimba lebih sedikit daripada kandungan azadirachtin pada biji mimba.

\section{METODE PENELITIAN}

Penelitian ini menggunakan jenis penelitian eksperimen dengan pendekatan kuantitatif. Rancangan percobaan yang 
digunakan dalam penelitian ini adalah dengan menggunakan Rancangan Acak Lengkap (RAL). Rancangan acak lengkap biasanya digunakan untuk percobaan- percobaan di laboratorium, rumah kaca, dan percobaan - percobaan terkendali lainnya. Tempat penelitian di Laboratorium IPA Biologi IAIN Mataram dan Laboraturium Kimia Analitik Universitas Mataram. Pelaksanaan penelitian ini dimulai pada bulan Desember tahun 2013. Populasi dalam penelitian ini adalah seluruh larva, pupa, dan lalat buah cabai (Bactrocera dorsalis L.) yang sudah dibiakkan dan Sampel yang akan digunakan dalam penelitian ini adalah 10 ekor lalat buah dalam setiap gelas plastik. Pada penelitian ini akan digunakan 25 buah gelas plastik, jadi jumlah sampel yang akan digunakan adalah 250 ekor lalat buah cabai yang akan diambil pada tempat yang biakan lalat buah cabai tersebut.

Data pada penelitian ini diperoleh dengan cara pengamatan langsung (observasi) yakni dengan cara melihat secara langsung gejala yang terjadi pada tiap perlakuan dan ulangan. Untuk mengetahui adanya pengaruh ekstrak daun mimba, data yang didapatkan dianalisis menggunakan ANOVA (Analysis of Varians) yang diuji pada taraf signifikansi $5 \%$.

\section{HASIL DAN PEMBAHASAN}

Parameter amatan dalam penelitian ini adalah dengan menghitung jumlah kematian lalat buah cabai setelah penyemprotan ekstrak daun mimba.

\section{Kematian (mortalitas) Pada Larva Lalat Buah Cabai}

Tabel 1. Data hasil perhitungan mortalitas (kematian) pada larva setelah penyemprotan ekstrak daun mimba selama 3 hari (\%)

\begin{tabular}{|c|c|c|c|c|c|c|}
\hline \multirow{3}{*}{ Ulangan } & \multicolumn{5}{|c|}{ Perlakuan } & \multirow{2}{*}{ Total } \\
\cline { 2 - 6 } & $\begin{array}{c}\mathrm{P}_{1} \\
(0 \%)\end{array}$ & $\begin{array}{c}\mathrm{P}_{2} \\
(5 \%)\end{array}$ & $\begin{array}{c}\mathrm{P}_{3} \\
(10 \%)\end{array}$ & $\begin{array}{c}\mathrm{P}_{4} \\
(15 \%)\end{array}$ & $\begin{array}{c}\mathrm{P}_{\mathrm{s}} \\
(20 \%)\end{array}$ & \\
\hline 1 & 10 & 40 & 70 & 70 & 70 & 260 \\
\hline 2 & 0 & 40 & 50 & 60 & 100 & 250 \\
\hline 3 & 20 & 30 & 50 & 60 & 80 & 240 \\
\hline
\end{tabular}




\begin{tabular}{|c|c|c|c|c|c|c|}
\hline 4 & 0 & 10 & 60 & 70 & 90 & 230 \\
\hline 5 & 10 & 30 & 40 & 80 & 80 & 240 \\
\hline $\begin{array}{c}\text { Total } \\
\text { Perlakuan }\end{array}$ & 40 & 150 & 270 & 340 & 420 & 1220 \\
\hline Rata-rata & 8 & 30 & 54 & 68 & 84 & \multicolumn{1}{|l}{} \\
\cline { 1 - 5 }
\end{tabular}

\section{Kematian (mortalitas) Pada Pupa Lalat Buah Cabai}

Tabel 2. Data hasil perhitungan mortalitas (kematian) pada pupa setelah penyemprotan ekstrak daun mimba selama 7 hari (\%)

\begin{tabular}{|c|c|c|c|c|c|c|}
\hline \multirow[b]{2}{*}{ Ulangan } & \multicolumn{5}{|c|}{ Perlakuan } & \multirow{2}{*}{$\begin{array}{c}\text { Total } \\
\text { Ulangan }\end{array}$} \\
\hline & $\begin{array}{l}P_{1} \\
(0 \%)\end{array}$ & $\begin{array}{l}\mathrm{P}_{2} \\
(5 \%)\end{array}$ & $\begin{array}{l}P_{3} \\
(10 \%)\end{array}$ & $\begin{array}{l}P_{4} \\
(15 \%)\end{array}$ & $\begin{array}{l}P_{s} \\
(20 \%)\end{array}$ & \\
\hline 1 & 10 & 0 & 0 & 50 & 10 & 70 \\
\hline 2 & 0 & 0 & 50 & 60 & 80 & 190 \\
\hline 3 & 0 & 30 & 0 & 0 & 50 & 80 \\
\hline 4 & 0 & 70 & 0 & 80 & 80 & 230 \\
\hline 5 & 40 & 0 & 80 & 0 & 0 & 120 \\
\hline $\begin{array}{c}\text { Total } \\
\text { Perlakuan }\end{array}$ & 50 & 100 & 130 & 190 & 220 & 690 \\
\hline Rata-rata & 10 & 20 & 26 & 38 & 44 & \\
\hline
\end{tabular}

\section{Kematian (mortalitas) Pada Imago Lalat Buah Cabai}

Tabel 3. Data hasil perhitungan mortalitas (kematian) pada imago setelah penyemprotan ekstrak daun mimba selama 3 hari $(\%)$

\begin{tabular}{|c|c|c|c|c|c|c|}
\hline \multirow[b]{2}{*}{ Ulangan } & \multicolumn{5}{|c|}{ Perlakuan } & \multirow{2}{*}{$\begin{array}{c}\text { Total } \\
\text { Ulangan }\end{array}$} \\
\hline & $\begin{array}{l}\mathrm{P}_{1} \\
(0 \%)\end{array}$ & $\begin{array}{l}\mathrm{P}_{2} \\
(5 \%)\end{array}$ & $\begin{array}{l}P_{3} \\
(10 \%)\end{array}$ & $\begin{array}{l}P_{4} \\
(15 \%)\end{array}$ & $\begin{array}{l}P_{s} \\
(20 \%)\end{array}$ & \\
\hline 1 & 0 & 20 & 50 & 50 & 60 & 180 \\
\hline 2 & 20 & 0 & 30 & 50 & 70 & 170 \\
\hline 3 & 0 & 10 & 20 & 30 & 50 & 110 \\
\hline 4 & 0 & 20 & 30 & 50 & 50 & 150 \\
\hline 5 & 10 & 50 & 40 & 60 & 60 & 220 \\
\hline $\begin{array}{c}\text { Total } \\
\text { Perlakuan } \\
\end{array}$ & 30 & 100 & 170 & 240 & 290 & 830 \\
\hline Rata-rata & 6 & 20 & 34 & 48 & 58 & \\
\hline
\end{tabular}


Untuk mengetahui pengaruh pengaruh insektisida ekstrakdaun mimba pada larva, pupa, dan imago, maka data tersebut dianalisis dengan menggunakan ANAVA (Analysis of Varians) yang diuji pada taraf signifikansi $5 \%$. Pengaruh ekstrak daun mimba terhadap mortalitas larva, pupa, dan imago lalat buah cabai dapat dilihat pada tabel berikut:

Tabel 4

Rekapitulasi Pengaruh Ekstrak Daun Mimba untuk Mengendalikan Larva, Pupa dan Imago Lalat Buah Cabai

\begin{tabular}{|l|c|c|c|}
\hline \multirow{2}{*}{ Perlakuan } & \multicolumn{3}{|c|}{ Paramater yang Diamati } \\
\cline { 2 - 4 } & $\begin{array}{c}\text { Persentase } \\
\text { kematian } \\
\text { larva (\%) }\end{array}$ & $\begin{array}{c}\text { Persentase } \\
\text { kematian } \\
\text { pupa (\%) }\end{array}$ & $\begin{array}{c}\text { Persentase } \\
\text { kematian } \\
\text { imago (\%) }\end{array}$ \\
\cline { 3 - 4 } P I & $8 \mathrm{a}$ & $10 \mathrm{a}$ & $6 \mathrm{a}$ \\
\hline P II & $30 \mathrm{~b}$ & $20 \mathrm{a}$ & $20 \mathrm{ab}$ \\
\hline P III & $54 \mathrm{c}$ & $26 \mathrm{a}$ & $34 \mathrm{bc}$ \\
\hline P IV & $68 \mathrm{~cd}$ & $38 \mathrm{a}$ & $48 \mathrm{~cd}$ \\
\hline P V & $84 \mathrm{~d}$ & $44 \mathrm{a}$ & $58 \mathrm{~d}$ \\
\hline
\end{tabular}

Keterangan : angka - angka yang diikuti oleh huruf yang sama pada kolom yang sama tidak berbeda nyata pada taraf 0,05 (Uji BNJ).

\section{Pengaruh ekstrak daun mimba pada larva}

Hasil penyemprotan ekstrak daun mimba pada larva lalat buah cabai menunjukkan adanya pengaruh, ini ditunjukkan dengan adanya kematian larva lalat buah pada setiap perlakuan. Rata - rata kematian larva tertinggi terdapat pada perlakuan $\mathrm{V}$ dengan konsentrasi ekstrak daun mimba $20 \%$ yaitu sampai $84 \%$ sedangkan yang terrendah terdapat pada perlakuan I dengan konsentrasi ekstrak daun mimba $0 \%$ mencapai 8\%. Dengan kata lain semakin tinggi konsentrasi ekstrak daun mimba, maka semakin tinggi pula tingkat kematian larva. Ini disebabkan karena semakin tinggi konsentrasi aplikasi ekstrak daun mimba yang digunakan maka diduga semakin tinggi zat azadirachtin yang ditinggalkan.

102 BIOTA: Jurnal Tadris IPA Biologi FITK IAIN Mataram 
Kematian (mortalitas) larva tersebut disebabkan oleh adanya kandungan zat yang terdapat pada ekstrak daun mimba tersebut yaitu yang pertama zat aktif yang terdapat pada daun mimba tersebut mempengaruhi atau mengganggu proses larva menjadi pupa, sehingga pupa gagal terbentuk dan akhirnya mati. Kedua, menghasilkan stimulan penolak makan spesifik berupa reseptor kimia (chemoreceptor) pada bagian mulut (mouthpart) yang bekerja bersama- sama dengan reseptor kimia lainnya yang mengganggu rangsangan untuk makan.

\section{Pengaruh ekstrak daun mimba pada Pupa}

Hasil penelitian penyemprotan ekstrak daun mimba pada pupa lalat buah cabai menunjukkan adanya pengaruh, ini ditunjukkan dengan adanya kematian pupa pada setiap perlakuan. Rata - rata kematian tertinggi terdapat pada perlakuan $\mathrm{V}$ dengan konsentrasi $20 \%$ yaitu mencapai $44 \%$ sedangkan yang terrendah terdapat pada perlakuan I dengan konsentrasi ekstrak daun mimba $0 \%$ yang mencapai $10 \%$. Dengan kata lain semakin tinggi konsentrasi ekstrak daun mimba, maka semakin tinggi pula tingkat kematian pupa. Ini disebabkan karena semakin tinggi konsentrasi aplikasi ekstrak daun mimba yang digunakan maka semakin tinggi zat azadirachtin yang ditinggalkan.

Kematian (mortalitas) pupa tersebut dapat dilihat dengan adanya pupa yang gagal atau tidak berhasil menjadi imago (serangga dewasa), ini dikarenakan adanya zat yang terdapat pada ekstrak daun mimba yang digunakan sebagai pestisida yang menyebabkan terganggunya proses metamorfosis pupa tersebut sehingga ada sebagian pupa yang mengalami plasmosis (cangkang kosong) sehingga meskipun pupa tersebut utuh dari luar, akan tetapi isi pupa tidak ada sehingga dapat disimpulkan pupa tersebut rusak dan tidak berhasil menjadi pupa. Kedua, zat aktif dalam daun mimba tersebut akan mengganggu proses neoroendocrine, otomatis dengan terganggunya sistem syaraf hama tersebut, maka pengaturan pertumbuhan pada hama tersebut akan terganggu. 


\section{Pengaruh ekstrak daun mimba pada imago}

Hasil penelitian penyemprotan ekstrak daun mimba pada imago (serangga dewasa) lalat buah cabai menunjukkan adanya pengaruh, ini ditunjukkan dengan adanya kematian imago lalat buah pada setiap perlakuan. Rata - rata kematian imago tertinggi terdapat pada perlakuan $\mathrm{V}$ dengan konsentrasi ekstrak daun mimba 20\% yaitu sampai 58\%, sedangkan yang terendah terdapat pada perlakuan I dengan konsentrasi ekstrak daun mimba 0\% mencapai 6\%. Dengan kata lain semakin tinggi konsentrasi ekstrak daun mimba, maka semakin tinggi pula tingkat kematian imago. Ini disebabkan karena semakin tinggi konsentrasi aplikasi ekstrak daun mimba yang digunakan maka diguga semakin tinggi zat azadirachtin yang ditinggalkan.

Pada penelitian ini zat azadirachtin bekerja sebagai penghambat proses ganti kulit dengan cara merusak sistem fisiologi serangga tersebut dan juga merusak sistem kerja hormon dan merusak sistem komunikasi kimiawi dalam proses ganti kulit. Proses ganti kulit tersebut dipicu dan dikendalikan oleh otak $\mathrm{AH}$ (activation hormone) dan ecdyson, dan disinilah fungsi azadirachtin sebaggai ecdyson blocker yang menghampat sistem komunikasi dalam proses pergantian kulit yang mengakibatkan serangga tersebut dimana dalam penelitian ini adalah Bactrocera dorsalis tidak mampu menghasilkan hormon-hormon penting dalam proses pergantian kulit sehingga pergantian kulit gagal yang lama kelamaan akan menyebabkan serangga tersebut mati. Disini juga efek azadirachtin pada serangga juga akan menghasilkan stimulan penolak makan berupa reseptor kimia (chemoreceptor) pada bagian mulut (mouthpart) yang bekerja bersama-sama dengan reseptor kimia lainnya yang mengganggu ransangan untuk makan.

Apabila serangga Bactrocera dorsalis telah mengalami keracunan oleh senyawa azadirachtin yang di sebabkan dari penyemprotan ekstrak daun mimba tersebut, maka proses fisiologinya akan terganggu yang ditandai dengan perubahan perilaku seperti penolakan makan, mengganggu pertumbuhan

104 BIOTA: Jurnal Tadris IPA Biologi FITK IAIN Mataram 
atau reproduksi secara struktural, dan larva menjadi tidak aktif (stress) dan akhirnya akan mengalami yang namanya kematian.

Perbedaan persentase kematian larva tersebut dikarenakan adanya perbedaan konsentrasi ekstrak daun mimba yang digunakan pada tiap perlakuan, dan menunjukkan semakin tinggi konsentrasi ekstrak daun mimba yang digunakan menunjukkam semakin tinggi rata-rata kematian pada imago tersebut. Ini juga dikuatkan dengan pengujian analisis data statistik yang menunjukkan bahwa terlihat perbedaan yang nyata (signifikan) dari setiap perlakuan. Sehingga dapat disimpulkan bahwa ekstrak daun mimba memiliki pengaruh yang nyata untuk mengendalikan imago lalat buah cabai tersebut.

\section{KESIMPULAN}

Berdasarkan pembahasan dan analisis data, serta terbatas pada hasil penelitian ini. Maka dapat disimpulkan bahwa ada pengaruh ekstrak daun mimba untuk mengendalikan hama lalat buah cabai pada stadium larva dan imago karna $F_{\text {hitung }}>F_{\text {tabel }}$ yaitu 41,51 > 2,87 pada larva dan 14,57 > 2,87 pada imago , sedangkan tidak berpengaruh untuk mengendalikan hama lalat buah pada stadium pupa karna $\mathrm{F}_{\text {hitung }}<\mathrm{F}_{\text {tabel yaitu }}$ 0,87 $<2,87$. Ini dibuktikan dengan semakin tinggi tingkat konsentrasi ekstrak daun mimba yang digunakan, maka semakin tinggi rata-rata jumlah kematian yang ditimbulkan.

\section{SARAN}

Berdasarkan simpulan yang diperoleh dalam penelitian ini, maka diajukan saran:

1. Perlu dilakukan penelitian lebih lanjut tentang pengaruh ekstrak daun mimba untuk mengendalikan hama lalat buah cabai (Bactrosera dorsalis). 
2. Untuk penelitian selanjutnya, sebaiknya penelitian yang akan dilakukan tidak hanya terbatas pada mortalitas saja, akan tetapi lebih mendalam pada proses gangguan fisiologi atau pertumbuhan hama serangga.

3. Disarankan kepada para petani untuk menggunakan pestisida nabati dari tumbuh- tumbuhan karena ramah lingkungan sebagai alternatif pengganti insektisida yang mengandung bahan kimia.

4. Diharapkan pihak-pihak yang terkait lebih aktif lagi mensosialisasikan tentang insektisida nabati, terutama yang berbahan tanaman yang dekat dengan masyarakat.

\section{DAFTAR PUSTAKA}

Agus Suyanto. 1994. Hama Sayur dan Buah. Jakarta: Penebar Swadaya.

Priyadi dan Suryo Sukendro. 2011. Memulai Usaha Si Pedas Cabai Rawit di Lahan dan Pot. Yogyakarta: Cahaya Atma

Abdul Hamid \& Munir Haryanto. 2011. Bertanam Cabai Hibrida Untuk Industri. Jakarta: PT Agromedia Pustaka.

Jumar. 2000. Entomologi Pertanian. Jakarta: Rhineka Cipta.

Sudarmo Subiyakto. 2005. Pestisida Nabati Pembuatan dan Pemanfaatannya. Yogyakarta: Kanisius.

Agus Kardinan dan Agus Ruhnayat. 2003. Mimba Budidaya dan Pemanfaatan. Jakarta: Penebar Swadaya.

Masyhuri dan M. Zainuddin. 2008. Metodologi Penelitian Praktis dan Aplikatif. Bandung: Refika Aditama.

Kusriningrum. perancangan percobaan. 2010. Surabaya: Airlangga University Press.

Bukhari, "Efektifitas Ekstrak Daun Mimba Terhadap Pengendalian Hama Plutella xylostella Pada Tanaman Kedele “, Journal SAINS Riset, vol. 1, no. 1, 2011, h. 5

Samsudin. "Biosintesa dan Cara Kerja Azadirachtin Sebagai Bahan Aktif Insektisida Nabati” , Semnas Pesnab, No 4, 2011, h. 65.

M. Sayuthi. " Ekstrak Biji Mimba ( Azadirachta indica A. Juss)". Biospecies. vol. 4. No 2, 2011, h. 11-17.

106 BIOTA: Jurnal Tadris IPA Biologi FITK IAIN Mataram 